\title{
Self-Efficacy Scale of Pre-School Teachers towards Mathematics Education in Pre-School Period
}

\author{
P. T. Seker ${ }^{1}$, F. Alisinanoglu ${ }^{2}$ \\ ${ }^{1}$ Department of Early Childhood Education Department, Education Faculty, Usak University, Usak, Turkey \\ ${ }^{2}$ Department of Child Development, Gelisim University, Istanbul, Turkey \\ Email: tugba.seker@usak.edu.tr, alisinanf@gmail.com
}

Received 21 January 2015; accepted 9 February 2015; published 11 February 2015

Copyright (C 2015 by authors and Scientific Research Publishing Inc.

This work is licensed under the Creative Commons Attribution International License (CC BY). http://creativecommons.org/licenses/by/4.0/

(c) (i) Open Access

\begin{abstract}
The study aims to develop an assessment instrument oriented to assess the self-efficacies of preschool teachers towards mathematics education. The assessment instrument was applied to 255 pre-school teachers working in Yenimahalle county of Ankara province in the 2012-2013 academic year. It was found out that the first factor of "Self-Efficacy of Pre-School Teachers towards Mathematics Education" explained $46.597 \%$ of the total variance, and the second factor explained $\mathbf{9 . 0 3 5 \%}$ of the total variance. In this sense, the total variance that the scale, and thus the construct validity of the scale was acceptable. The reliability co-efficient of the first factor of the scale is 0.951 ; the reliability co-efficient if the second factor is 0.951 ; and the total reliability co-efficient is 0.967 .
\end{abstract}

\section{Keywords}

Pre-School Education, Early Mathematics Education, Pre-School Teacher

\section{Introduction}

Mathematics can appear in individuals' lives in every stage of life. Accordingly, today, mathematics education has an important place in the education process of children. Children's developing positive attitude towards Mathematics is closely related to the education they take in the early years of their lives and to the guidance of the pre-school teachers that they meet (Akman, 2002).

In the studies conducted on the quality of education in pre-school period, one of the most emphasized issues is the teacher-student communication. In order to give a quality education, the teacher must have an adaptive, creative, investigative, and flexible characteristic (Kandır, İnal, \& Özbey, 2010). 
For the teachers, being ready for the mathematics education is crucial and occasionally difficult situation. Generally, to teach mathematics, one must have a strong mathematic and pedagogic background. National Council of Teachers of Mathematics (NCTM), in its Professional Standards for Teaching Mathematics (1991), emphasizes that "the teacher must endeavor to make the concepts and principles of mathematics deeply understood and to provide that the subjects of mathematics or its relations with other disciplines are formed". In pre-school period, which is outstanding in raising the individuals and accepted as a critical period in one's life, laying the foundations of the academic skills, especially mathematics skills, is essential. Therefore, as it is well known, the person who will support the developing of these skills in those years is the pre-school teacher who is taken as a role model after the child's parents. It is thought that the ideas, beliefs and self-efficacy beliefs of the pre-school teachers on mathematics education affect the implementations in the education process (Şeker, 2013).

People have many self-efficacy perceptions that they need to show in their daily lives. "Self-efficacy" is one of the key concepts of Albert Bandura's Social Learning Theory that has been the topic of many studies in recent years. According to Bandura (1997), self-efficacy is an effective quality in the forming of the behaviours and is defined as "the self attitude of the individuals related to their capacity to organize necessary activities to perform well and to succeed" (Şahin, Ogelman, \& Ekici, 2011).

The gaining of the necessary attitude, behavior, knowledge and skills requires teacher training programs to include general culture, field information, and professional knowledge. It is a well known fact that teachers must have the field information about the subject that they teach. In addition to the field information, the teacher must have skills and techniques related to that occupation in order to perform their job (Celep, 2005). The pre-school teachers are expected to have high levels of self-efficacy as well as having professional knowledge and skills.

According to Bandura, the important thing is the judgments of the people towards performing a behavior successfully or not, because, those judgments will definitely lead to some results. In other words, as those who have high self-efficacy will be able to get the results that they want, their expectations for the results will be shaped accordingly (Akbaş \& Çelikkaleli, 2006).

Bandura (1986) emphasized self-efficacy plays an important role in determining behaviour and feelings of confidence about a specific problem are crucial to an individual's capacity to solve that problem (Schulz, 2005). Self-efficiacy proved to be a better predictor of behavior toward unfamiliar threats than did past performance (Bandura, 1977).

The self-efficacy belief of the teacher affects the quality of the teaching, methods and techniques used, participation of the students to learning, student's understanding of the lesson, and thus, it defines the success of the studies. Hence, the well-trained prospective teachers are expected to have high self-efficacy beliefs before everything else (Üredi, I \& Üredi, L., 2005). Preschool teachers' self efficacy beliefs towards mathematics education is thought to be influenced the teachers' activities during the education process. By analysing the indications held upon beliefs, Pajares (1992), stated that teachers' beliefs are formed too prematurely; the earlier a belief settles in an individual, the harder it would get to change that belief; the later the belief settles in, the weaker it gets and that it would easily be replaced (Güven, Karataş, Öztürk, Arslan, \& Gürsoy, 2013).

Platas (2008), made his studies concerning preschool teachers' opinions and sufficieny. In his study, he indicated that the mathematics education exercises in preschool classes were influenced by the teachers' opinions at a major level.

Once the resources are observed, researches analysing the Turkish teachers' opinions regarding to mathematics education as a whole are limited. As a result, these researches are of great importance in terms of education.

Because of the mathematics educations' characteristics, contents and application process being distinct from the era followed by the preschool, it is of great importance that the testing devices are being developed targeting to improve the preschool teachers' opinions and self-sufficiency relating to this field being dominant and dependant of the preschool education. The testing devices that would be developed in this field are required to be planned in accordance with the preschool education contents.

\section{Method}

"Self-Efficacy Scale of Pre-School Teachers towards Mathematics Education" was developed to define the selfefficacies of the teachers working in pre-school institutions towards the teaching of mathematics to pre-school period children. The scale was graded in 5 Likert-type items and the gradations are "Totally Agree - Agree - Neutral - Disagree - Totally Disagree". There are 36 items in the Self-Efficacy Scale and all of the items are positive.

In the development study of "Self-Efficacy Scale of Pre-School Teachers towards Mathematics Education", 
the Likert-type scale developing steps described by Tezbaşaran (2008) were followed. These steps are as follows:

1) Defining of the feature to be assessed

a) Defining the scope of the feature

b) Defining of the observable markers suitable for the content: Experimental Statements.

2) Organization of the experimental scale and pilot study

a) Preparing the scale material

b) Preparing the instructions and the answering layout

c) The layout of the items in the scale

d) Preliminary view

e) Pilot study

3) The analysis of the data obtained from the experimental scale

a) Scoring of the answers for the items

b) Calculation of the raw scores that the individuals get from the scale

c) The characteristics of the distribution of raw scores

d) The characteristics of the distribution of item scores

e) Item analysis

(Tezbașaran, 2008)

For the first step of developing "The Self-Efficacy Scale of Pre-School Teachers towards Mathematics Education”, the relevant literature was reviewed. Afterwards, the definition of self-efficacy was done by consulting the ideas of 10 field experts and 40 experimental statements, which are all positive, towards self-efficacy, and related to mathematics education in pre-school period, were formed.

The instructions including the purpose of the scale, the number of items in the scale, the way of answering the items, the estimated time to answer the items, the identity of the scale-developer were prepared and the items were ordered in the scale. Initially, the opinions of one expert of Turkish Language and one expert of assessment and evaluation were granted; the first regulations were done based on their feedback. Later, the opinions 10 experts working in the pre-school education department at university were taken via "Expert Opinion Form".

\section{Results}

When the findings of the scale were reviewed; initially in the evaluation of the field experts' opinions, the content validity index (CVI) of each item was calculated. This index is used for each item in defining whether the experts find that item necessary or not. Since the number of experts is 10, it is concluded that the items whose CVI is above than 0.64 are necessary (Yurdugül, 2005). The CVI of 38 items out of 40, about which the expert opinions were granted, were above 0.64 and the CVI of the 2 items $\left(23^{\text {rd }}\right.$ and $40^{\text {th }}$ ones) were lower than 0.64 . Those 2 items were omitted from the scale and the necessary corrections were done on the remaining items based on the opinions of the experts.

After the corrections based on the expert opinions were conducted, the scale was applied to 3 pre-school teachers and the items were reviewed in terms of their meanings and applicability. There were no corrections from the teachers about the items in the scale.

The 38 items in the experimental self-efficacy scale, with the instruction, were applied to 255 school teachers who did not participate in the real study. Based on the findings of the preliminary study, explanatory factor analysis was done for the scale's validity and reliability.

\section{Explanatory Factor Analysis Results}

In order to statistically define the construct validity of the "The Self-Efficacy Scale of Pre-School Teachers towards Mathematics Education”, explanatory factor analysis (EFA) was carried out. EFA aims to reach from lots of variables (items) to the a few definable constructs that those variables can explain together (Büyüköztürk, 2008).

Initially, to test whether the scale is appropriate for the factor analysis, KMO (Kaiser-Mayer-Olkin) and Barlett tests were applied. The calculated KMO test was $92.7 \%$ (0.927). Kaiser states that this value becomes perfect as it gets closer to 1 (perfect in 0.90 'ies, very good in 0.80 'ies, medium in 0.70 'ies and 0.60 'ies, and bad in 0.50 'ies), and it becomes unacceptable if it is under 0.50 (Tavşancıl, 2006). The calculated KMO values show that the data set is perfect for the factor analysis. The Barlett's test was found significant after the analysis ( $p<$ 0.01). The high correlation found between the variables shows that the data set is appropriate for the factor 
analysis (Kalayc1, 2009).

In the first analysis of 38 items in the scale done without the rotation of the factors, it is observed that there are 7 factors whose eigenvalues are above than 1 . However, when Figure 1 was examined, it is understood that two factors, whose variances explained by their eigenvalues are higher than other factors, are dominant.

After the factor number of the scale was determined, the factor analysis was repeated and factor load values related to the two-factor structure were examined. In the explanatory factor analysis, whether an item in the scale will take place in factor to be defined or not is related to high load value of it with that factor. The items that have high load values with a factor are named as the items that assess the structure defined by the factor. As well as the desired item factor load value is generally 0.45 or above, the items whose factor load values are 0.30 can be kept in the scale (Tabachnik \& Fidell, 1989). In this sense, $21^{\text {st }}$ and $27^{\text {th }}$ items whose factor load values are below than 0.30 were omitted from the scale. The analysis was carried on with the remaining 36 items in the experimental form and it was detected that the scale was gathered under 2 factors after the repeated Varimax rotation results. The calculated factor load values of the items based on the analysis were shown in Table 1 .

In Table 1, the calculated factor load values of the items based on the explanatory factor analysis are seen. The first factor of the self-efficacy scale, which has a 2 -factor structure, explains the $46.597 \%$ of the total variance, and the second factor explains the $9.035 \%$ of the total variance. The two factors explain the $55.632 \%$ of the total variance together.

Büyüköztürk (2008) states that $30 \%$ or more for the variance explained in one-factor scales could be accepted as sufficient. Besides, a value between $40 \%$ and $60 \%$ for the variance explained in multi-factor patterns could be accepted as sufficient (Çokluk et al., 2010). Therefore, it can be concluded that the variance that the scale explains, thus the construct validity could be acceptable.

In order to test the reliability of the scale, for each factor and for the overall scale, Cronbach's Alpha reliability coefficient was calculated. The reliability coefficient of the first dimension of the scale is 0.95 ; the reliability coefficient of the second dimension is 0.951 ; the reliability coefficient of the overall scale is 0.967 . Kalayc1 (2009) states that the scales that have a reliability coefficient of 0.80 or above are accepted as highly reliable. Based on these findings, it was found out that the developed scale and its two factors are highly reliable.

In naming of the factors of the 2-factor self-efficacy scale, by taking the opinions of the field experts, the first factor that have 20 items was named as self-efficacy towards preparing mathematics activities in pre-school period and the second factor including the other items was named as self-efficacy towards applying mathematics activities in pre-school period.

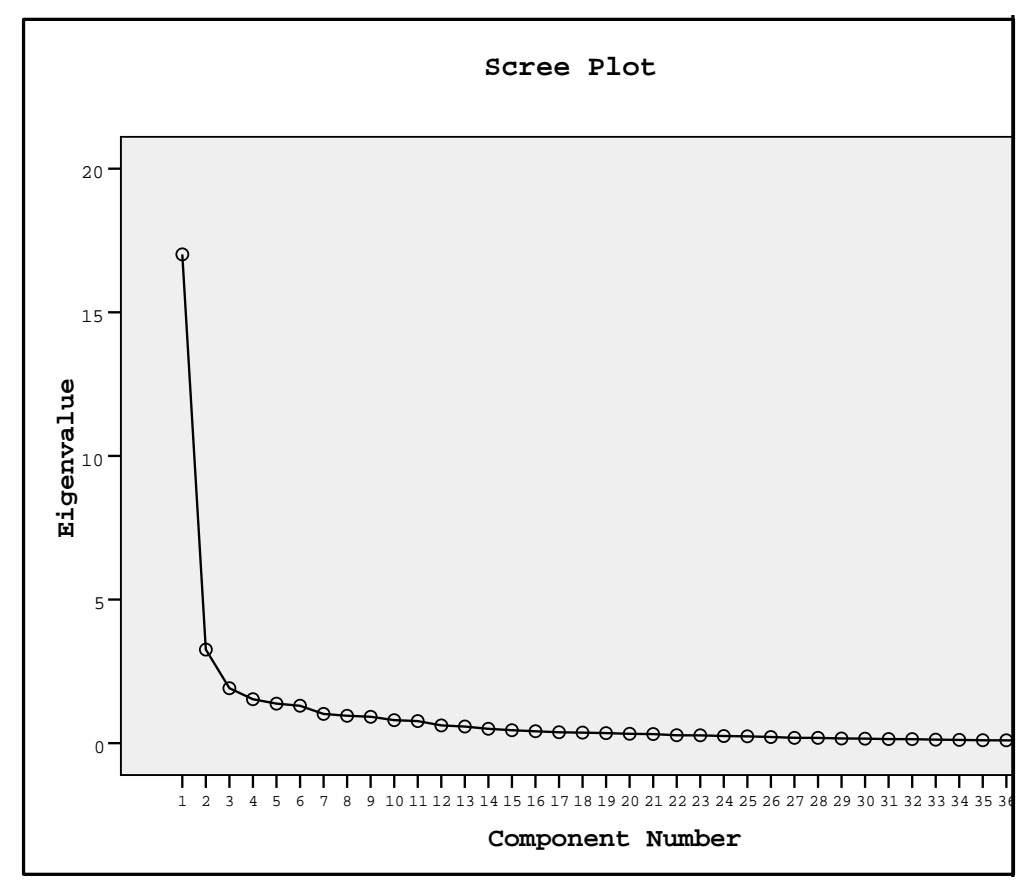

Figure 1. Scree plot of the eigenvalues of the items. 
Table 1. Factor load values of the items based on the varimax rotation results.

\begin{tabular}{|c|c|c|}
\hline Items & Factor 1 & Factor 2 \\
\hline S13 & 0.770 & 0.116 \\
\hline S12 & 0.761 & 0.246 \\
\hline S9 & 0.721 & 0.230 \\
\hline S10 & 0.713 & 0.304 \\
\hline S8 & 0.713 & 0.292 \\
\hline S15 & 0.709 & 0.356 \\
\hline S6 & 0.707 & 0.207 \\
\hline S7 & 0.706 & 0.252 \\
\hline S16 & 0.701 & 0.299 \\
\hline S5 & 0.693 & 0.351 \\
\hline S3 & 0.693 & 0.248 \\
\hline S11 & 0.677 & 0.239 \\
\hline S4 & 0.674 & 0.302 \\
\hline S2 & 0.674 & 0.223 \\
\hline S14 & 0.670 & 0.189 \\
\hline S17 & 0.577 & 0.301 \\
\hline S20 & 0.571 & 0.180 \\
\hline S1 & 0.566 & 0.304 \\
\hline S18 & 0.555 & 0.385 \\
\hline S19 & 0.504 & 0.330 \\
\hline S32 & 0.167 & 0.850 \\
\hline S34 & 0.230 & 0.821 \\
\hline S31 & 0.197 & 0.796 \\
\hline S35 & 0.267 & 0.787 \\
\hline S30 & 0.244 & 0.783 \\
\hline S37 & 0.241 & 0.779 \\
\hline S33 & 0.246 & 0.741 \\
\hline S36 & 0.253 & 0.698 \\
\hline S38 & 0.321 & 0.683 \\
\hline S28 & 0.236 & 0.680 \\
\hline S29 & 0.308 & 0.637 \\
\hline S23 & 0.455 & 0.630 \\
\hline S25 & 0.427 & 0.608 \\
\hline S22 & 0.358 & 0.596 \\
\hline S24 & 0.487 & 0.593 \\
\hline S26 & 0.283 & 0.505 \\
\hline
\end{tabular}

\section{Discussion}

When the steps for preparing the scale and the analyses are examined, factor load values of the items based on the explanatory factor analysis are seen. The first factor of the self-efficacy scale, which has a 2-factor structure, explains the $46.597 \%$ of the total variance, and the second factor explains the $9.035 \%$ of the total variance. The 
two factors explain the $55.632 \%$ of the total variance together. Büyüköztürk (2008) states that $30 \%$ or more for the variance explained in one-factor scales could be accepted as sufficient. Besides, a value between $40 \%$ and $60 \%$ for the variance explained in multi-factor patterns could be accepted as sufficient (Çokluk et al., 2010). Therefore, it can be concluded that the variance that the scale explains, thus the construct validity could be acceptable.

\section{Conclusions}

In order to test the reliability of the scale, for each factor and for the overall scale, Cronbach's Alpha reliability coefficient was calculated. The reliability coefficient of the first dimension of the scale is 0.95 ; the reliability coefficient of the second dimension is 0.951 ; the reliability coefficient of the overall scale is 0.967 . Kalayc1 (2009) states that the scales that have a reliability coefficient of 0.80 or above are accepted as highly reliable. Based on these findings, it was found out that the developed scale and its two factors are highly reliable.

Aksu (2008) made some analysis according to the differentiation of the primary school, science and preschool teacher candidates according to their beliefs of self-efficacy towards mathematics education, gender, majors and departments at high school. After the research of Aksu, it was determined that teacher candidates had high tendency in terms of the self-efficacy towards mathematics education and sub-dimensions of handling. It was found that there were no meaningful differences among teacher candidates in terms of their departments. The number of the studies which were done to measure the perception of the self-efficacy and beliefs of the preschool teachers towards mathematics education is really limited. For example, in their studies, Aslan, Bilaloğlu and Aktaş Arnas (2006) made individual interviews with 22 preschool teachers at independent kindergartens about how often they include mathematics education in their daily schedules, which sources they use for mathematics education, which methods they use and how they assess themselves in applying the methods. At the end of the studies, it was found after the observations that although most of the teachers stated that they included mathematics activities in their daily schedules, only half of them used these activities. In such situation, observation method should be used to support the scale results in the studies. Studies are generally about teacher candidates. There has been limited research about self efficiacy beliefs of teachers as it relates to prescholers' math competence. So the present study has the findings to contribute to the field.

\section{References}

Akbaş, A., \& Çelikkaleli, Ö. (2006). Sınıf öğretmeni adaylarının fen öğretimi öz-yeterlik inançlarının cinsiyet, öğrenim türü ve üniversitelerine göre incelenmesi. Mersin Üniversitesi Ĕ̆itim Fakültesi Dergisi, 2, 98-110.

Aksu, H. H. (2008). Öğretmen adaylarının matematik öğretimine ilişkin öz-yeterlilik inançları. Abant İzzet Baysal Üniversitesi Ĕ̈itim Fakültesi Dergisi, 8, 161-170.

Aslan, Bilaloğlu, \& Aktaş Arnas (2006). Okul Öncesi Öğretmenlerinin Günlük Programda Yer Verdikleri Matematik Etkinliklerinin ve $\mathrm{Bu}$ Etkinlikleri Uygulama Biçimlerinin İncelenmesi. Avrupa Birliği Uyum Sürecinde Okul Öncesi Eğitimin Bugünü ve Geleceği Sempozyumu, Girne, Kıbrıs. Cilt I, Sayfa: 243-257. İstanbul: Ya-Pa.

Akman, B. (2002). Okulöncesi dönemde matematik. Hacettepe Üniversitesi Eğitim Fakültesi Dergisi, 23, 244-248.

Bandura, A. (1977). Self-Efficacy: Toward a Unifying Theory of Behavioral Change. Psychological Review, 84, $191-215$. http://dx.doi.org/10.1037/0033-295X.84.2.191

Büyüköztürk, Ş. (2008). Sosyal Bilimler İçin Veri Analizi El Kitabı. Ístatistik, Araştırma Deseni SPSS Uygulamaları ve Yorum (6. bask1). Ankara: Pegem A.

Celep, C. (2005). Meslek olarak öğretmenlik. In: C. Celep (Ed.), Meslek Olarak Öğretmenlik (s. 23-50). Ankara: Anı.

Çokluk, Ö., Şekercioğlu, G., \& Büyüköztürk, Ş. (2010). Sosyal bilimler için çok değişkenli istatistik SPSS ve LISREL uygulamaları. Ankara: Pegem A.

Güven, B., Karataş, İ., Öztürk, Y., Arslan, S., \& Gürsoy, K. (2013). Okul Öncesi Öğretmenlerinin ve Öğretmen Adaylarının Okul Öncesi Matematik Eğitimine İlişkin İnançların Belirlenmesine Yönelik Bir Ölçek Geliştirme Çalışması. İlköğretim Online, 12, 969-980. http://ilkogretim-online.org.tr/vol12say4/v12s4m5.pdf

Kalaycı, Ş. (2009). SPSS Uygulamalı Çok Değişkenli İstatistik Teknikleri. Ankara: Asil.

Kandır, A., İnal, G., \& Özbey, S. (2010). Okul Öncesi Ĕ̆itimde Program (1) Kuramsal Temeller. İstanbul: Morpa.

Platas, L. (2008). Measuring Teachers' Knowledge of Early Mathematical Development and Their Beliefs about Mathematics Teaching and Learning in the Preschool Classroom. Ph.D. Dissertation, Berkeley, CA: University of California. 
Şahin, H., Gülay Ogelman, H., \& Ekici, H. (2011). Okul Öncesi Öğretmen Adaylarının Akademik Öz-Yeterlik Düzeylerine Etki Eden Faktörlerin Değerlendirilmesi. Çă̆daş Eğitim Dergisi, 36, 13-22.

Şeker, P. T. (2013). Okul Öncesi Öğretmenlerinin Okul Öncesi Dönemde Matematik Ĕ̈itimine Yönelik İnanç ve Özyeterliklerinin 48-60 Aylık Çocukların Matematik Yeteneklerine Etkisinin Incelenmesi. Yayınlanmamış Doktora Tezi, Ankara: Gazi Üniversitesi, Eğitim Bilimleri Enstitüsü.

Tabachnik, B. G., \& Fidell, L. S. (1989). Using Multivariale Statistics (2nd ed.). Cambridge: Harper \& Row.

Tavşanc1l, E. (2006). Tutumların ölçülmesi ve spss ile veri analizi (3 bask1). Ankara: Nobel.

Tezbaşaran, A. (2008). Likert Tipi Ölçek Hazırlama Kılavuzu. Mersin: Türk Psikologlar Derneği.

Üredi, I., \& Üredi, L (2005). Sınıf öğretmeni adaylarının cinsiyetlerine, bulundukları sınıflara ve başarı düzeylerine göre fen öğretimine ilişkin öz-yeterlilik inançlarının karşılaştırılması. Yeditepe Üniversitesi Ĕ̆itim Fakültesi Dergisi, 7, 2.

Yurdugül, H. (2005). Ölçek Geliştirme Çalışmalarında Kapsam Geçerliği için Kapsam Geçerlik İndekslerinin Kullanılması. XIV. Ulusal Eğitim Bilimleri Kongresi, Denizli. 
Scientific Research Publishing (SCIRP) is one of the largest Open Access journal publishers. It is currently publishing more than 200 open access, online, peer-reviewed journals covering a wide range of academic disciplines. SCIRP serves the worldwide academic communities and contributes to the progress and application of science with its publication.

Other selected journals from SCIRP are listed as below. Submit your manuscript to us via either submit@scirp.org or Online Submission Portal.
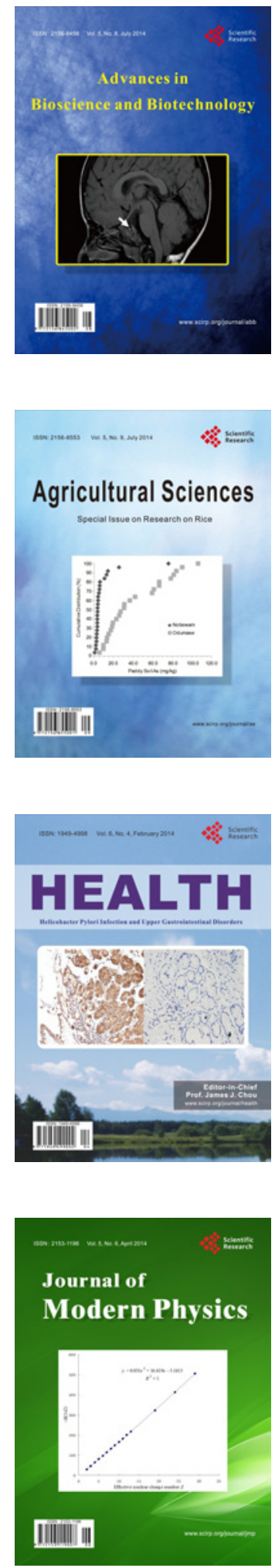
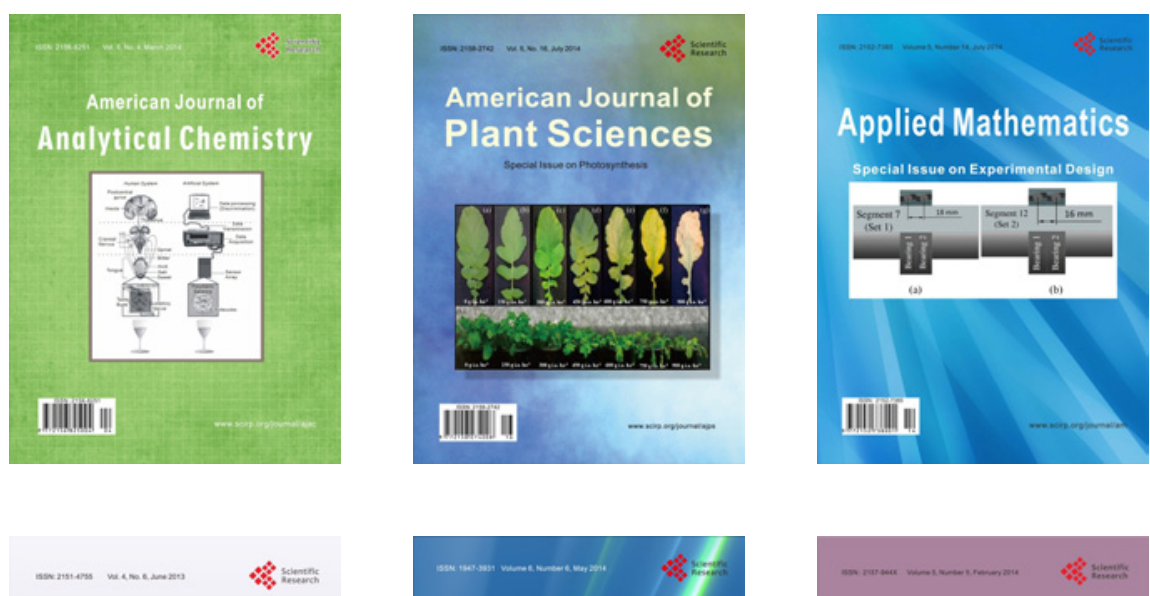

Creative Education
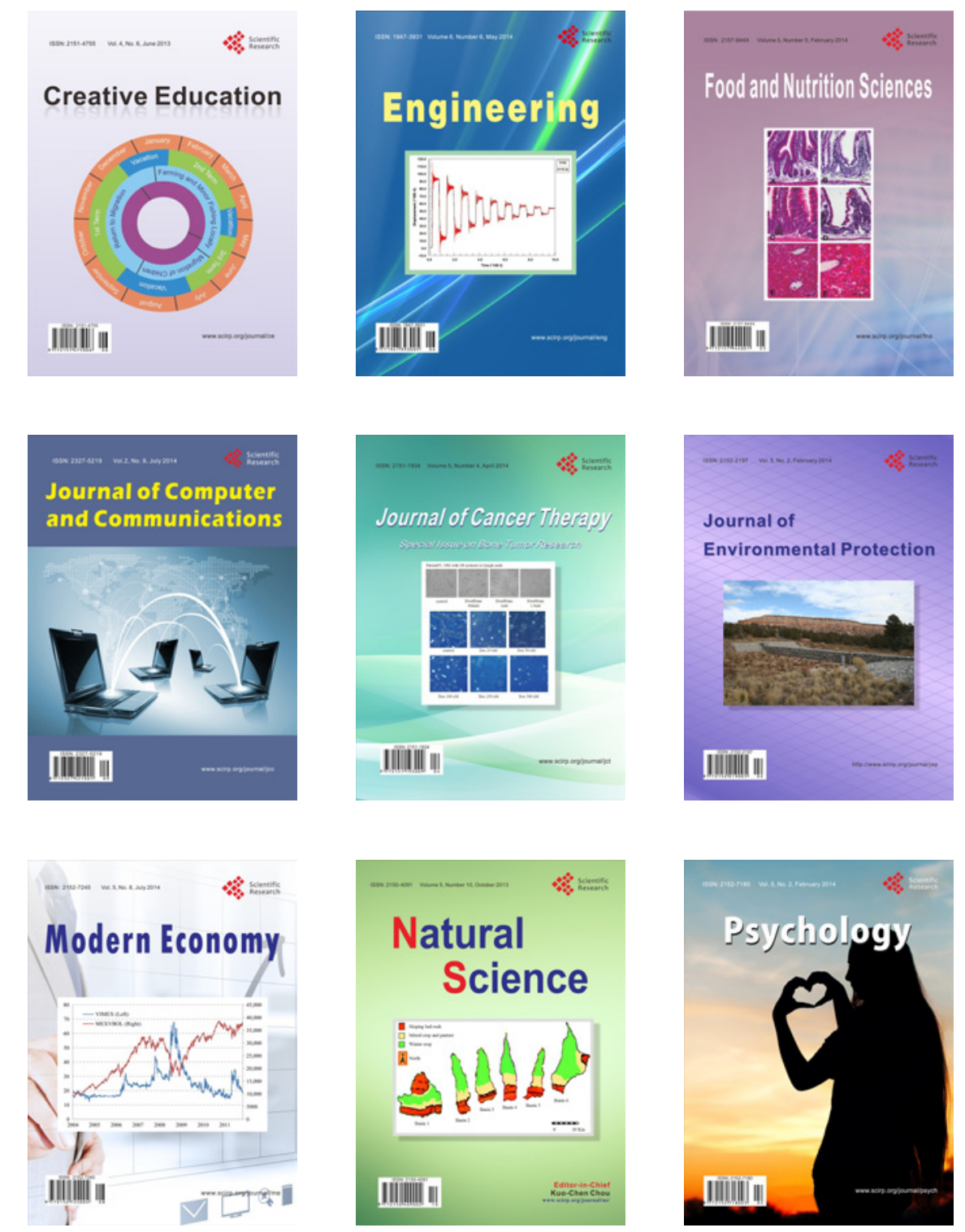